ROCZNIKI NAUK PRAWNYCH

Tom XXX, numer $3-2020$

DOI: https://doi.org/10.18290/rnp20303-1

\author{
MICHALINA DUDA-HYZ
}

\title{
KSZTAŁTOWANIE SIĘ LINII ORZECZNICZYCH W ZAKRESIE OPODATKOWANIA VAT SPRZEDAŻY PRZEZ ROLNIKÓW DZIAŁEK POD ZABUDOWE
}

\begin{abstract}
WSTĘP
Jednym z najbardziej kontrowersyjnych zagadnień podatkowych, z którym $\mathrm{w}$ ostatniej dekadzie przyszło się mierzyć właścicielom gospodarstw rolnych, był problem opodatkowania VAT sprzedaży nieruchomości pod zabudowę ${ }^{1}$. Normujące powyższą kwestię przepisy ustawy o podatku od towarów i usług ${ }^{2}$ stanowiły nie tylko oś licznych sporów sądowych pomiędzy podatnikami a organami podatkowymi, ale także źródło prawdziwych dramatów, czego najbardziej bolesnym wyrazem było szeroko komentowane samobójstwo jednego z rolników ${ }^{3}$. W praktyce gospodarczej wątpliwości rodziły

Dr hab. Michalina Duda-Hyz - Katedra Finansów i Prawa Finansowego, Instytut Nauk Prawnych, Wydział Prawa, Prawa Kanonicznego i Administracji Katolickiego Uniwersytetu Lubelskiego Jana Pawła II, Al. Racławickie 14, 20-950 Lublin; e-mail: dudami@kul.lublin.pl; ORCID: https://orcid.org/0000-0001-7058-3481

${ }^{1} \mathrm{Na}$ powyższe zagadnienie zwracał uwagę m.in. Związek Zawodowy Rolników Rzeczypospolitej „Solidarni”. Zob. interpelacja nr $15866 \mathrm{w}$ sprawie wykładni przepisów ustawy o podatku od towarów i usług w zakresie sprzedaży gruntów rolnych, Sejm VIII kadencji, http://www.sejm. gov.pl/sejm8.nsf/interpelacja.xsp?documentId=E9AA9F950154D9D5C12581A900370FFF [dostęp: 2.10.2018].

${ }^{2}$ Ustawa z dnia 11 marca 2004 r. o podatku od towarów i usług, tekst jedn. Dz. U. 2018 poz. 2174, z późn. zm., dalej jako: ustawa o podatku od towarów i usług.

${ }^{3}$ Zob. Kolejna ofiara „Przyjaznego państwa”. Rolnik spod Jeleniej Góry nie wytrzymat konfrontacji z fiskusem i popetnit samobójstwo, https://wpolityce.pl/polityka/160589-kolejna-ofiaraprzyjaznego-panstwa-rolnik-spod-jeleniej-gory-nie-wytrzymal-konfrontacji-z-fiskusem-i-popelnil -samobojstwo [dostęp: 27.09.2017]; B. MARCZUK, Rolnik zabił się bo nie wytrzymat starcia z urzędnikami, ,Rzeczpospolita” z dnia 25 czerwca 2013 r.
\end{abstract}


przede wszystkim sytuacje, w których dana osoba nabyła działkę lub działki przeznaczone do użytkowania rolniczego, a następnie - wskutek zmiany planu zagospodarowania przestrzennego lub wydania decyzji o warunkach zabudowy - nieruchomości te zostały przeznaczone pod zabudowę. W konsekwencji rolnik dokonywał ich podziału na kilka, niejednokrotnie nawet kilkadziesiąt działek budowlanych, a następnie ich sprzedaży. Nabycie działek przeznaczonych do użytkowania rolniczego mogło nastąpić w każdy, dopuszczony w świetle przepisów prawa polskiego sposób ${ }^{4}$, przy czym w praktyce najwięcej kontrowersji rodziły sytuacje, w których rolnicy nabywali wskazane nieruchomości w drodze darowizny lub spadku po rodzicach bądź innych członkach rodziny albo zakupili grunty od osób fizycznych lub Agencji Nieruchomości Rolnych.

Celem niniejszego artykułu jest dokonanie przeglądu orzecznictwa w zakresie opodatkowania sprzedaży nieruchomości pod zabudowę, które uprzednio były przeznaczone do użytkowania rolniczego. Opracowanie zostało przygotowane w ramach projektu badawczego finansowanego przez Narodowe Centrum Nauki Nowy model opodatkowania rolnictwa w Polsce ${ }^{5}$. Ponieważ jednym z celów tego projektu była identyfikacja obszarów, w zakresie których przepisy ustawy o podatku od towarów i usług stanowiły na przestrzeni lat przedmiot licznych wątpliwości interpretacyjnych w praktyce gospodarczej, analizie poddano także orzeczenia zapadłe na gruncie nieobowiązującego stanu prawnego.

1. KSZTAŁTOWANIE SIĘ LINII ORZECZNICZYCH W OKRESIE POPRZEDZAJĄCYM WYROK TRYBUNAŁU SPRAWIEDLIWOŚCI W SPRAWACH POŁĄCZONYCH C-180/10 I C-181/10

W pierwszych latach obowiązywania ustawy o podatku od towarów i usług w orzecznictwie sądów administracyjnych dominowało stanowisko zbieżne z ocenami wyrażanymi przez organy podatkowe, jakoby podmiot dokonujący sprzedaży działek powstałych w wyniku podziału własnego gospodarstwa rolnego był $\mathrm{z}$ tego tytułu podatnikiem VAT. Uzasadnienia dla powyższej

\footnotetext{
${ }^{4}$ Szerzej zob. J. ORŁowSKI, Dostawa terenów budowlanych oraz przeznaczonych pod zabudowę, w: Wyktadnia i stosowanie prawa podatkowego. Węzłowe problemy, red. B. Brzeziński, SIP Lex/el. 2013.

${ }^{5}$ Grant OPUS nr wniosku 2013/09/B/HS5/04503, kierownik grantu dr hab. Paweł Smoleń, prof. KUL.
} 
tezy poszukiwano w treści definicji legalnej działalności gospodarczej, w myśl której do kategorii tej zaliczały się również czynności wykonane jednorazowo w okolicznościach wskazujących na zamiar ich wykonywania w sposób częstotliwy ${ }^{6}$. W ocenie niektórych składów orzekających z chwilą dokonania podziału geodezyjnego działek osoba przejawiała zamiar prowadzenia działalności gospodarczej polegającej na sprzedaży działek w sposób częstotliwy, a tym samym stawała się podatnikiem podatku od towarów i usług z tytułu dostawy rzeczonych gruntów ${ }^{7}$. Wyrażano również pogląd, że podatnikiem prowadzącym działalność polegającą na handlu nieruchomościami jest nie tylko osoba, która nabywa nieruchomości w celu ich odsprzedaży, ale także osoba, która będąc rolnikiem dokonywała podziału nieruchomości gospodarstwa rolnego na działki o rozmiarach wykluczających możliwość przyjęcia, że będą służyły działalności rolniczej ${ }^{8}$. Sukcesywną sprzedaż działek powstałych w wyniku podziału własnego gospodarstwa rolnego uznawano zatem za prowadzenie działalności gospodarczej. Niektóre składy orzekające odmiennie oceniały sytuację, w której osoba fizyczna nabyła działkę w drodze dziedziczenia. Podnoszono, że dostawa gruntu w takich okolicznościach nie jest działalnością handlowca, ta polega bowiem na kupowaniu towarów w celu ich odsprzedaży. W sytuacji nabycia w drodze dziedziczenia działanie podatnika polegające na podziale działek wskazuje jedynie na chęć uzyskania dobrej ceny za ich sprzedaż ${ }^{9}$. Należy również podkreślić, że $\mathrm{w}$ tym samym czasie w judykaturze stopniowo zaczęła kształtować się linia orzecznicza, w której jako nieuprawnioną oceniano tezę, że sam fakt dokonywania sprzedaży podzielonej na działki nieruchomości gruntowej przesądza - ze względu na oczywistą powtarzalność transakcji - o prowadzeniu przez sprzedającego działalności gospodarczej ${ }^{10}$. W tym aspekcie na szczególną

\footnotetext{
${ }^{6}$ Art. 15 ust. 2 ustawy o podatku od towarów i usług w brzmieniu obowiązującym do końca marca $2013 \mathrm{r}$.

${ }^{7}$ Zob. np.: wyrok WSA w Olsztynie z dnia 9 lutego 2006 r., sygn. akt I SAS/Ol 11/06, SIP Lex nr 945238; wyrok WSA w Olsztynie z dnia 6 kwietnia 2006 r., sygn. akt I SA/O1 112/06, SIP Legalis nr 489513.

${ }^{8}$ Wyrok WSA w Olsztynie z dnia 7 września 2006 r., sygn. akt I SA/O1 302/06, SIP Lex nr 945392.

${ }^{9}$ Zob. wyrok WSA w Szczecinie z dnia 30 marca 2006 r., sygn. akt I SA/Sz 602/05, SIP Lex 858336

${ }^{10}$ Zob. wyrok WSA we Wrocławiu z dnia 26 stycznia 2007 r., sygn. akt I SA/Wr 1688/06, CBOSA. W ocenie sądów nie można było danego podmiotu uznać za podmiot prowadzący działalność gospodarczą tylko dlatego, że wykonał on daną czynność w okolicznościach wskazujących na zamiar jej wykonywania w sposób częstotliwy. Zob. wyrok WSA w Warszawie z dnia 21 lutego 2007 r., sygn. akt III SA/Wa 4176/06, SIP Lex nr 322257.
} 
uwagę zasługuje wyrok Naczelnego Sądu Administracyjnego z 24 kwietnia 2007 r. W orzeczeniu tym Sąd zwrócił uwagę na niedoskonałość legislacyjną polskiego ustawodawcy w zakresie implementacji przepisów VI Dyrektywy statuujących definicję działalności gospodarczej oraz upoważniających państwa członkowskie do uznania za podatnika każdego, kto okazjonalnie zawiera transakcje związane z działalnością gospodarczą, w szczególności dokonuje dostawy działek budowlanych ${ }^{11}$. Odwołując się do stanowiska zajmowanego w doktrynie, Naczelny Sąd Administracyjny wskazał, że z przepisów VI Dyrektywy, odpowiadającym im regulacji Dyrektywy 2006/122/WE oraz unormowań ustawy o podatku od towarów i usług wynika, że: „okazjonalność (sporadyczność) czynności, względnie jednorazowe ich wykonywanie, tworzy z danej osoby podatnika wyłącznie w przypadku, gdy te okazjonalnie lub jednorazowo wykonywane czynności są czynnościami wykonywanymi w związku z działalnością producentów, handlowców lub usługodawców [...] oraz rolników, a także działalności osób wykonujących wolne zawody" ${ }^{12}$. W ocenie Sądu pod pojęciem „handel” należy rozumieć dokonywanie w sposób zorganizowany zakupów towarów w celu ich odsprzedaży. W związku z powyższym opodatkowaniu podlega, chociażby jednorazowo, czynność zrealizowana $\mathrm{w}$ formie zorganizowanej sprzedaży towaru, poprzedzonej zakupem dokonanym w celu jego odsprzedaży oraz wskazująca na zamiar jej kontynuacji $\mathrm{w}$ tej formie ${ }^{13}$. Warto również dodać, że wskazane stanowisko spotkało się z jednoznaczną aprobatą doktryny ${ }^{14}$. W konsekwencji w judykaturze zaczęto akcentować fakt, że do przyjęcia opodatkowania danej czynności VAT nie wystarcza sam fakt wykonania czynności mieszczącej się w zakresie przedmiotowym podatku, lecz czynność ta winna być dokonana przez podatnika, a w sytuacjach dotyczących sprzedaży działek najczęściej handlowca prowadzącego samodzielnie działalność gospodarczą ${ }^{15}$.

\footnotetext{
${ }^{11}$ Zob. wyrok NSA z dnia 24 kwietnia 2007 r., sygn. akt I FSK 603/06, SIP Lex nr 261626.

12 Tamże.

13 Tamże.

${ }^{14}$ Zob. K. LASIŃSKI-SUlECKI, Glosa do wyroku NSA z dnia 24 kwietnia 2007 r., sygn. akt I FSK 603/2006, SIP Lex; P. KARWACKI, K. KoSAKOWSKA, Glosa do wyroku NSA z dnia 24 kwietnia 2007 r., I FSK 603/06 oraz do wyroków WSA z dnia 26 stycznia 2007 r., I SA/Wr 1688/06 i z dnia 21 lutego 2007 r., III SA/Wa 4176/06, „Prawo i Podatki” (2011), nr 15, s. 17-18.

${ }^{15} \mathrm{~W}$ orzecznictwie akcentowano również fakt, iż do grona podatników nie zaliczają się osoby fizyczne dokonujące sprzedaży majątku osobistego, który nie został nabyty w celu jego odsprzedaży, nawet jeżeli sprzedaż dokonywana jest kilkukrotnie. Zob. wyrok WSA w Olsztynie z dnia 22 lutego 2007 r., sygn. akt I SA/O1 1/07, SIP Lex nr 328151; wyrok WSA we Wrocławiu z dnia 9 marca 2007 r., sygn. akt I SA/Wr 1849/06, CBOSA; wyrok WSA we Wrocławiu z dnia 19 kwietnia 2007 r., sygn. akt I SA/Wr 82/07, SIP Lex nr 1009494; wyrok WSA w Poznaniu z dnia
} 
Tożsamą tezę Naczelny Sąd Administracyjny wyraził w wyroku wydanym w składzie siedmiu sędziów 29 października 2007 r. ${ }^{16}$ Co istotne, w orzeczeniu tym Sąd uznał również, że Polska skorzystała z przewidzianej w przepisach prawa unijnego możliwości uznania za podatnika każdego, kto okazjonalnie zawiera transakcje związane z działalnością gospodarczą, podkreślając jednak, że realizacja owej opcji nastąpiła w sposób wysoce niedoskonały, tj. poprzez rozszerzenie definicji legalnej działalności gospodarczej. W ocenie Sądu ustawa o podatku od towarów i usług realizowała możliwość uznania za podatnika każdego, kto okazjonalnie dokonuje transakcji gospodarczych związanych z działalnością gospodarczą poprzez zawarcie w treści definicji działalności gospodarczej wyrażenia: „czynności wykonanej jednorazowo w okolicznościach wskazujących na zamiar wykonywania czynności w sposób częstotliwy". Powyższe nie uzasadniało jednak konkluzji, że do uznania danego podmiotu za podatnika wystarczające było samo spełnienie przesłanki zamiaru wykonywania czynności w sposób częstotliwy ${ }^{17}$. W judykaturze wyrażano również pogląd, że w przypadku działalności gospodarczej w zakresie handlu zamiar częstotliwego wykonywania czynności musi być ujawniony już w momencie nabycia towaru, a nie w momencie jego sprzedaży. Tym samym nie można wiązać nabycia nieruchomości w drodze spadku lub darowizny $\mathrm{z}$ nabyciem $\mathrm{w}$ ramach obrotu profesjonalnego ${ }^{18}$. Podkreślenia wymaga także to, że zdaniem sądów administracyjnych o zamiarze prowadzenia działalności gospodarczej polegającej na sprzedaży nieruchomości nie świadczył sam fakt dokonania podziału geodezyjnego nieruchomości ${ }^{19}$.

$\mathrm{Na}$ tle utrwalonego w doktrynie i judykaturze stanowiska dotyczącego konieczności występowania w odniesieniu do konkretnej czynności w charakterze podatnika VAT pojawił się kolejny problem stanowiący przedmiot sporów pomiędzy rolnikami a organami podatkowymi. Była to kwestia oceny, czy w przypadku sprzedaży działek budowlanych wydzielonych z nie-

16 listopada 2007 r., sygn. akt I SA/Po 1071/07, SIP Lex nr 469009; wyrok WSA w Lublinie z dnia 21 listopada 2007 r., sygn. akt I SA/Lu 524/07, SIP Lex nr 475639.

${ }^{16}$ Zob. wyrok NSA (7) z dnia 29 października 2007 r., sygn. akt I FPS 3/07, ONSA i WSA 2008, nr 1, poz. 8. Powyższa teza została z aprobatą przyjęta w doktrynie. Zob. M. MiLliTz, Sprzedaż działek budowlanych z majątku niezwiązanego z dziatalnościa gospodarcza. Glosa do wyroku NSA z dnia 29 października 2007 r., I FPS 3/07, ,Przegląd Podatkowy” (2008), nr 2, s. 42-47.

${ }^{17}$ Tamże. Zob. także wyrok WSA w Warszawie $\mathrm{z}$ dnia 4 stycznia 2008 r., sygn. akt III SA/Wa 1948/07, SIP Lex nr 413775.

${ }^{18}$ Zob. wyrok WSA w Gliwicach z dnia 25 stycznia 2008 r., sygn. akt III SA/G1 764/07, SIP Lex nr 493222.

${ }^{19}$ Zob. wyrok WSA w Olsztynie z dnia 23 stycznia 2008 r., sygn. akt I SA/O1 546/07, SIP Lex nr 466262; wyrok NSA z dnia 7 lipca 2009 r., sygn. akt I FSK 558/09, SIP Lex nr 564490. 
ruchomości, które uprzednio służyły prowadzeniu działalności rolniczej powyższa przesłanka jest spełniona $\mathrm{z}$ racji tego, że sprzedaży dokonuje osoba prowadząca działalność gospodarczą będącą działalnością rolniczą. Zdaniem niektórych składów orzekających wielokrotna sprzedaż wydzielonych w wyniku podziału gospodarstwa rolnego działek budowlanych stanowiła czynność podlegającą VAT. Bez znaczenia pozostawał zatem fakt, że sama sprzedaż działek nie należy do istoty działalności prowadzonego przez podatnika gospodarstwa rolnego ${ }^{20}$. Analizując powyższe zagadnienie w judykaturze trafnie zwrócono uwagę na to, że z uwagi na specyfikę gospodarstw rolnych na terytorium Polski sam fakt bycia rolnikiem i posiadania gospodarstwa rolnego nie zawsze oznacza, że dany podmiot wykonuje działalność rolniczą w rozumieniu ustawy. Możliwa jest bowiem sytuacja, w której produkty rolne są wytwarzane wyłącznie w celu zaspokojenia potrzeb własnych i rodziny ${ }^{21}$. W przypadku, gdy dana osoba nie prowadziła działalności rolniczej w rozumieniu ustawy o podatku od towarów i usług, należało uznać, że grunty wchodzące w skład gospodarstwa stanowiły majątek prywatny ${ }^{22}$. Z kolei w sytuacji, gdy rolnik wytwarzał produkty rolne celem ich dostawy, sprzedaż gruntu rolnego jako składnika gospodarstwa rolnego oceniano jako czynność dokonywaną w ramach prowadzonej działalności gospodarczej, chyba że grunty te zostały wycofane $\mathrm{z}$ działalności rolniczej. Podkreślenia wymaga przy tym to, że samej zmiany $\mathrm{w}$ planie zagospodarowania przestrzennego nie uznawano za przesłankę wystarczającą do uznania, że grunty stanowią element majątku osobistego ${ }^{23}$.

Przeciwne stanowisko zajmowały składy orzekające, w ocenie których sam fakt bycia rolnikiem nie uzasadniał opodatkowania VAT sprzedaży działek przeznaczonych na cele budowlane jako czynności wykonywanych w ramach prowadzonej działalności gospodarczej. Uzasadniając powyższy pogląd podnoszono, że wcześniejsze wykorzystywanie gruntów do produkcji nie wystarcza do sformułowania tezy, w myśl której ich sprzedaż stanowi obrót dokonywany $\mathrm{w}$ ramach prowadzonej przez rolnika działalności gospodarczej, tj. działalności rolniczej ${ }^{24}$. Jeżeli bowiem grunty użytkowane

${ }^{20}$ Zob. wyrok WSA w Poznaniu z dnia 13 grudnia 2007 r., sygn. akt I SA/Po 1072/07, SIP Lex nr 468154. Zob. także wyrok WSA w Olsztynie z dnia 28 listopada 2007 r., sygn. akt I SA/Ol 586/07, SIP Lex nr 456837.

${ }^{21}$ Zob. wyrok NSA z dnia 3 października 2008 r., sygn. akt 1129/07, SIP Legalis nr 186612.

${ }^{22}$ Stanowisko takie wyrażano również w doktrynie. Zob. A. ŻARKOwSKA, Sprzedaż niezabudowanych działek wykorzystywanych rolniczo nie podlega opodatkowaniu podatkiem od towarów i ustug, „Doradztwo Podatkowe” (2015), nr 7, s. 32-33.

${ }^{23}$ Zob. wyrok NSA z dnia 3 października 2008 r., sygn. akt 1129/07, SIP Legalis nr 186612.

${ }^{24}$ Zob. wyrok NSA z dnia 7 lipca 2009 r., sygn. akt I FSK 558/09, SIP Lex nr 564490; wyrok 
pierwotnie $\mathrm{w}$ gospodarstwie rolnym $\mathrm{w}$ planach zagospodarowania przestrzennego zostały ujęte jako przeznaczone dla celów budowlanych, to przestały być użytkami rolnymi, co w świetle definicji legalnej gospodarstwa rolnego oznacza, że nie mogły służyć prowadzeniu działalności rolniczej ${ }^{25}$. Zwracano również uwagę, że grunt nie jest produktem rolnym w rozumieniu ustawy, zatem obrót nieruchomościami nie mieści się w zakresie definicji legalnej działalności rolniczej ${ }^{26}$.

\section{KSZTAŁTOWANIE SIĘ LINII ORZECZNICZYCH PO WYDANIU PRZEZ TRYBUNAŁ SPRAWIEDLIWOŚCI UNII EUROPEJSKIEJ WYROKU W SPRAWACH POŁĄCZONYCH C-180/10 I C-181/10}

Istotnym etapem kształtowania się linii orzeczniczych w zakresie opodatkowania nieruchomości przeznaczonych pod zabudowę było skierowanie do Trybunału Sprawiedliwości Unii Europejskiej pytań prejudycjalnych dotyczących uznania za podatnika osoby fizycznej, która prowadziła działalność rolniczą na gruncie nabytym ze zwolnieniem od podatku od wartości dodanej i przekształconym wskutek zmiany planu zagospodarowania przestrzennego w grunt przeznaczony pod zabudowę ${ }^{27}$. Podejmując rozstrzygnięcie w przedmiocie powyższych pytań, Trybunał Sprawiedliwości sformułował

WSA we Wrocławiu z dnia 17 stycznia 2008 r., sygn. akt I SA/Wr 1607/07, SIP Lex nr 492011.

${ }^{25}$ Zob. wyrok WSA w Warszawie z dnia 7 lutego 2008 r., sygn. akt III SA/Wa 1215/07, SIP Lex nr 464199. Tożsame stanowisko wyrażano również w doktrynie. Zob. D. DoMiniK, Czy sprzedaż działki budowlanej przez rolnika jest opodatkowana VAT?, „Jurysdykcja Podatkowa” (2008), nr 6, s. 30.

${ }^{26}$ Zob. wyrok WSA we Wrocławiu z dnia 23 kwietnia 2009 r., sygn. akt I SA/Wr 1377/08, SIP Lex 171726. Zob. także wyrok WSA we Wrocławiu z dnia 17 marca 2009 r., sygn. akt I SA/Wr 1229/08, SIP Lex nr 166621.

${ }^{27}$ Postanowieniem z dnia 9 marca 2010 r. (sygn. akt I FSK 2039/08, SIP Lex nr 578181) NSA wystąpił z pytaniem prejudycjalnym, czy osoba fizyczna, która na nieruchomości gruntowej prowadziła działalność rolniczą, a następnie z uwagi na zmianę planów zagospodarowania przestrzennego, która nastąpiła z przyczyn niezależnych od woli tej osoby, zakończyła tę działalność i przekwalifikowała majątek na majątek prywatny, dokonała jego podziału na mniejsze części i rozpoczęła jego zbywanie, jest z tego tytułu podatnikiem VAT. Z kolei w sprawie Emilian Kuć, Halina Jezierska-Kuć NSA zwrócił się z pytaniem, czy rolnika ryczałtowego, który dokonuje sprzedaży dziełek służących uprzednio jego działalności rolniczej, przeznaczonych w planie zagospodarowania przestrzennego gminy pod zabudowę mieszkaniowo-usługową, a nabytych jako grunty rolne, należy uznać za podatnika zobowiązanego do rozliczenia VAT z tytułu tej sprzedaży na zasadach ogólnych. Zob. postanowienie NSA z dnia 9 marca 2010 r., sygn. akt I FSK 2134/08, SIP Lex 578181. 
następujące tezy. Po pierwsze wskazał, że dostawę gruntu przeznaczonego pod zabudowę należy uznać za objętą podatkiem od wartości dodanej na podstawie prawa krajowego państwa członkowskiego, jeżeli państwo to skorzystało z możliwości uznania za podatnika każdego, kto okazjonalnie dokonuje transakcji związanych $\mathrm{z}$ działalnością gospodarczą w rozumieniu Dyrektywy. Nie ma przy tym znaczenia częstotliwość tego rodzaju transakcji ani to, czy sprzedawca prowadzi działalność producenta, handlowca lub usługodawcy. Za podlegające opodatkowaniu nie można natomiast uznać transakcji stanowiących jedynie czynności związane ze zwykłym wykonywaniem prawa własności ${ }^{28}$. Po drugie odniósł się do statusu prawnopodatkowego osoby fizycznej prowadzącej działalność rolniczą, która dokonywała sprzedaży gruntu pod zabudowę w sytuacji, gdy grunt ten został nabyty ze zwolnieniem z VAT i przekształcony wskutek zmiany planu zagospodarowania przestrzennego, niezależnie od woli sprzedającego, w grunt przeznaczony pod zabudowę. W ocenie Trybunału, jeżeli sprzedaż następuje w ramach zarządu majątkiem własnym tej osoby, nie można jej uznać za podatnika $\mathrm{VAT}^{29}$. Warto podkreślić, że nawiązując do wyrażanych już wcześniej w polskiej judykaturze stanowisk, Trybunał wskazał, że sama liczba i zakres transakcji nie mają w tym zakresie charakteru decydującego, gdyż dużych transakcji można również dokonywać jako czynności osobistych. Przesądzająca nie jest także okoliczność, że przed sprzedażą zainteresowany dokonał podziału gruntu w celu osiągnięcia wyższej ceny łącznej. Takie działanie może bowiem odnosić się do zarządzania majątkiem prywatnym. Zdaniem Trybunału odmiennie należy natomiast oceniać sytuację, gdy zainteresowany podejmuje aktywne działania (np. polegające na uzbrojeniu terenu albo na działaniach marketingowych) w zakresie obrotu nieruchomościami, angażując środki podobne do wykorzystywanych przez producentów, handlowców i usługodawców w rozumieniu przepisów Dyrektywy. Jednocześnie Trybunał jednoznacznie wskazał, że bez znaczenia pozostaje w tym zakresie okoliczność, że dana osoba korzysta ze statusu rolnika ryczałtowego ${ }^{30}$.

Wbrew oczekiwaniom ze strony podmiotów zainteresowanych sprzedażą nieruchomości gruntowych nabytych jako działki rolne a sprzedawanych jako tereny przeznaczone pod zabudowę, wyrok Trybunału Sprawiedliwości

\footnotetext{
${ }^{28}$ Wyrok TSUE z dnia 15 września 2011 r. w sprawach połączonych C-180/10 (Jarosław Słaby) i C-181/10 (Emilian Kuć, Halina Jezierska-Kuć), Dz. U. C 319 z 29.10.2011, s. 8, pkt 49, dalej jako wyrok TSUE w sprawach C-180/10 i C-181/10.

${ }^{29}$ Tamże, pkt 50.

30 Tamże, pkt 52.
} 
nie usunął wszystkich wątpliwości związanych z opodatkowaniem tego rodzaju transakcji ${ }^{31}$. Należy bowiem zauważyć, że Trybunał nie rozstrzygnął, czy w Polsce mamy do czynienia $\mathrm{z}$ opodatkowaniem transakcji dokonywanych okazjonalnie, pozostawiając rzeczoną kwestię ocenie sądów krajowych. Stwierdził natomiast, że transpozycja dyrektywy do prawa krajowego nie wymaga koniecznie literalnego powtórzenia jej przepisów w wyraźnej i specjalnie do tego przeznaczonej normie prawa ${ }^{32}$. W tym zakresie w judykaturze zaczęła się kształtować linia orzecznicza przeciwna do wyrażonego w 2007 r. stanowiska o wadliwej implementacji przepisów dotyczących opodatkowania transakcji dokonywanych okazjonalnie. Zdecydowanie zaczął bowiem dominować pogląd, że w ustawie o podatku od towarów i usług brak było takiego jednoznacznego i precyzyjnego unormowania, z którego wynikałoby, że Polska skorzystała $\mathrm{z}$ uprawnienia do opodatkowania tego rodzaju transakcji ${ }^{33}$. Również $\mathrm{w}$ doktrynie wyrażano opinię, że w ustawie o podatku od towarów i usług nie została zrealizowana opcja opodatkowania transakcji dokonywanych okazjonalnie. Wskazywano, że obowiązkiem podatkowym objęto dostawę terenów budowlanych oraz przeznaczonych pod zabudowę, dokonywaną wyłącznie w związku ze statusem podmiotu wykonującego ową czynność jako prowadzącego działalność gospodarczą bądź też mogącego

\footnotetext{
${ }^{31}$ Wyrok ten spotkał się również z krytycznym przyjęciem w doktrynie. Zob. A. WESOŁOWSKA, Glosa do wyroku TS z dnia 15 września 2011 r., C-180/10 i C-181/10, SIP Lex; Ł. MATUSIAKIEWICZ, VAT od działek sprzedawanych przez rolników ryczałtowych - watpliwości pozostaja, ,Nieruchomości” (2011), nr 12, SIP Legalis.

${ }^{32}$ Wyrok TSUE w sprawach połączonych C-180/10 i C-181/10, pkt 34.

${ }^{33}$ Zob. wyrok NSA z dnia 7 października 2011 r., sygn. akt I FSK 1289/10, SIP Lex nr 1095735; wyrok NSA z dnia 9 listopada 2011 r., sygn. akt I FSK 1656/11, SIP Lex nr 1148488; wyrok NSA z dnia 10 listopada 2011 r., sygn. akt I FSK 83/11, SIP Legalis nr 427891; wyrok NSA z dnia 8 grudnia 2011 r., sygn. akt I FSK 1747/11, SIP Legalis nr 1945148; wyrok NSA z dnia 11 stycznia 2012 r., sygn. akt I FSK 1830/11, SIP Legalis nr 507323; wyrok NSA z dnia 25 stycznia 2012 r., sygn. akt I FSK 1868/11, SIP Legalis nr 448275; wyrok NSA z dnia 16 lutego 2012 r., sygn. akt I FSK 1742/11, SIP Lex 1136173; wyrok NSA z dnia 21 lutego 2012 r., sygn. akt I FSK 1848/11, SIP Lex nr 1136181; wyrok NSA z dnia 22 lutego 2012 r., sygn. akt I FSK 307/11, SIP Legalis nr 473806; wyrok NSA z dnia 19 kwietnia 2012 r., sygn. akt I FSK 1118/11, CBOSA; wyrok WSA we Wrocławiu z dnia 23 stycznia 2012 r., sygn. akt I SA/Wr 1393/11, SIP Lex nr 1113492; wyrok WSA w Warszawie z dnia 27 stycznia 2012 r., sygn. akt III SA/Wa 929/11, CBOSA; wyrok WSA w Szczecinie z dnia 8 lutego 2012 r., sygn. akt I SA/Sz 1026/11, SIP Legalis nr 474697; wyrok WSA w Łodzi z dnia 16 lutego 2012 r., sygn. akt I SA/Łd 53/12, CBOSA; wyrok WSA we Wrocławiu z dnia 29 lutego 2012 r., sygn. akt I SA/Wr 141/11, SIP Lex nr 1137377; wyrok WSA w Szczecinie z dnia 10 maja 2012 r., sygn. akt I SA/Sz 214/12, SIP Lex nr 1166122; wyrok WSA w Warszawie z dnia 22 lutego 2013 r., sygn. akt III SA/Wa 2088/12, SIP Legalis 772735. Por. wyrok WSA w Olsztynie z dnia 12 marca 2014 r., sygn. akt I SA/O1 140/14, SIP Lex nr 1450066.
} 
zostać uznanym za prowadzącego taką działalność w przypadku dokonywania wyłącznie takich transakcji ${ }^{34}$.

Stanowisko, iż w przypadku dostawy terenów przeznaczonych pod zabudowę bezwzględną przesłanką powstania obowiązku podatkowego jest prowadzenie działalności gospodarczej zaowocowało z kolei bogatym dorobkiem orzeczniczym wskazującym na kryteria, jakimi należy kierować się przy rozstrzyganiu, czy w danym przypadku można mówić o prowadzeniu działalności gospodarczej, czy jedynie o zarządzie majątkiem prywatnym. W tym zakresie w judykaturze wskazano szereg przesłanek, zastrzegając jednocześnie, że na prowadzenie działalności gospodarczej musi wskazywać kilka okoliczności, a nie stwierdzenie zaistnienia wyłącznie jednej z nich.

Po pierwsze podnoszono, że nabycie danej nieruchomości winno nastąpić w celu jej odsprzedaży, tj. w celach handlowych a nie prywatnych ${ }^{35}$. Należy jednak zwrócić uwagę, że w odniesieniu do tego kryterium przyszło również sądom administracyjnym wypowiadać pogląd przeciwny. Wskazywano, że brak wykazania zamiaru dalszej odsprzedaży nieruchomości w dacie jej nabycia nie jest przesłanką skutkującą brakiem możliwości uznania czynności sprzedaży działek budowlanych za wykonanie ich w ramach działalności gospodarczej $^{36}$. Drugie z przedstawionych stanowisk wydaje się zdecydowa-

\footnotetext{
${ }^{34}$ Zob. J. ORŁowSKI, Dostawa terenu, SIP Lex/el. 2013.

${ }^{35}$ Zob. wyrok NSA z dnia 10 listopada 2011 r., sygn. akt I FSK 83/11, SIP Legalis nr 427891; wyrok NSA z dnia 25 stycznia 2012 r., sygn. akt I FSK 1870/11, CBOSA; wyrok NSA z dnia 3 lutego 2012 r., sygn. akt I FSK 1877/11, SIP Legalis nr 497243; wyrok WSA w Warszawie z dnia 11 kwietnia 2011 r., sygn. akt III SA/Wa 2418/10, CBOSA; wyrok WSA w Kielcach z dnia 27 października 2011 r., sygn. akt I SA/Ke 463/11, SIP Lex nr 1131672; wyrok WSA w Olsztynie z dnia 16 listopada 2011 r., sygn. akt I SA/O1 625/11, CBOSA; wyrok WSA w Bydgoszczy z dnia 5 grudnia 2011 r., sygn. akt I SA/Bd 494/11, SIP Legalis nr 428411; wyroki WSA w Bydgoszczy z dnia 7 grudnia 2011 r., sygn. akt I SA/Bd 490/11 i I SA/Bd 492/11, CBOSA; wyrok WSA w Warszawie z dnia 14 grudnia 2011 r., sygn. akt III SA/Wa 433/12, SIP Legalis nr 811441; wyrok WSA w Gdańsku z dnia 20 grudnia 2011 r., sygn. akt I SA/Gd 1087/11, CBOSA; wyrok WSA w Bydgoszczy z dnia 31 stycznia 2012 r., sygn. akt I SA/Bd 744/11, SIP Legalis nr 866970; wyroki WSA w Poznaniu z dnia 29 lutego 2012 r., sygn. akt I SA/Po 106/12 i I SA/Po 107/12, CBOSA; wyrok WSA w Bydgoszczy z dnia 1 czerwca 2012 r., sygn. akt I SA/Bd 291/12, CBOSA; wyrok WSA w Warszawie z dnia 2 sierpnia 2012 r., sygn. akt III SA/Wa 2592/11, SIP Legalis nr 546415; wyrok WSA w Olsztynie z dnia 13 września 2012 r., sygn. akt I SA/O1 367/12, SIP Legalis nr 544850.

${ }^{36}$ Zob. wyrok NSA z dnia 11 stycznia 2012 r., sygn. akt I FSK 1700/11, CBOSA; wyrok NSA z dnia 22 lutego 2012 r., sygn. akt I FSK 308/11, SIP Legalis nr 473807; wyrok NSA z dnia 22 lutego 2012 r., sygn. akt I FSK 528/11, SIP Lex nr 473834; wyrok NSA z dnia 22 lutego 2012 r., sygn. akt I FSK 515/11, SIP Legalis 473818; wyrok WSA w Gorzowie Wielkopolskim z dnia 3 listopada 2011 r., sygn. akt I SA/Go 900/11, SIP Legalis nr 869964; wyrok WSA w Gorzowie Wielkopolskim z dnia 24 listopada 2011 r., sygn. akt I SA/Go 901/11, SIP Lex 1150062; wyrok WSA w Łodzi z dnia 13 kwietnia 2012 r., sygn. akt I SA/Ld 242/12, CBOSA.
} 
nie bardziej przekonujące. Uznanie danego podmiotu za podatnika VAT jest bowiem uzależnione nie od zamiaru, z jakim dana nieruchomość została nabyta, lecz od podejmowania aktywnych działań w zakresie obrotu nieruchomościami, przy zastosowaniu środków podobnych do wykorzystywanych przez producentów, handlowców i usługodawców.

Po drugie, uwzględniając treść wyroku Trybunału Sprawiedliwości podkreślano, że o prowadzeniu działalności gospodarczej świadczy podejmowanie przez podmiot dokonujący sprzedaży nieruchomości aktywnych działań, które $\mathrm{z}$ jednej strony mają służyć realizacji danych transakcji, a z drugiej angażują środki podobne do wykorzystywanych przez producentów, handlowców i usługodawców w rozumieniu ustawy. Jako przykłady takich działań wskazywano m.in.: (1) uzbrojenie terenu lub zobowiązanie się przez sprzedającego do wykonania prac związanych np. z wybudowaniem domu, wykonaniem instalacji sanitarnej, elektrycznej itp., (2) uzyskanie przed sprzedażą decyzji o warunkach zagospodarowania terenu (zabudowy), (3) dokonanie podziału nieruchomości, (4) wystąpienie o opracowanie planu zagospodarowania przestrzennego dla sprzedawanego obszaru, zwłaszcza w sytuacji gdy sprzedawca był już podatnikiem w zakresie usług budowlanych, deweloperskich czy innych tego rodzaju usług o zbliżonym charakterze, (5) wydzielenie dróg wewnętrznych, (6) udział w nakładach na zagospodarowanie działek, (7) działania marketingowe podjęte w celu sprzedaży działek, np. ogłaszanie ofert sprzedaży w gazecie, (8) ustanowienie pełnomocnika do sprzedaży działek czy (9) zakup kolejnych działek, a w szczególności przeznaczenie części dochodu ze sprzedaży działek na zakup innej nieruchomości celem jej podziału i dalszej sprzedaży ${ }^{37}$. W judykaturze trafnie zwracano

\footnotetext{
${ }^{37}$ Zob. np.: wyrok NSA z dnia 9 listopada 2011 r., sygn. akt I FSK 1656/11, SIP Lex nr 1148488; wyrok NSA z dnia 11 listopada 2011 r., sygn. akt I FSK 1666/11, SIP Legalis nr 406914; wyrok NSA z dnia 16 listopada 2011 r., sygn. akt I FSK 110/11, SIP Legalis nr 399824; wyrok NSA z dnia 8 grudnia 2011 r., sygn. akt I FSK 478/11, SIP Legalis nr 1945144; wyrok NSA z dnia 15 grudnia 2011 r., sygn. akt I FSK 1695/11, SIP Legalis nr 417530; wyrok NSA z dnia 12 stycznia 2012 r., sygn. akt I FSK 1865/11, SIP Legalis nr 507291; wyrok NSA z dnia 13 stycznia 2012 r., sygn. akt I FSK 1696/11, SIP Legalis 507233; wyrok NSA z dnia 26 stycznia 2012 r., sygn. akt I FSK 1819/11, SIP Legalis nr 466958; wyrok NSA z dnia 31 stycznia 2012 r., sygn. akt I FSK 1667/11, SIP Legalis nr 531018; wyrok NSA z dnia 21 lutego 2012 r., sygn. akt I FSK 1849/11, SIP Legalis nr 537895; wyrok NSA z dnia 19 kwietnia 2012 r., sygn. akt I FSK 1118/11; SIP Legalis nr 741235; wyrok NSA z dnia 5 lutego 2012 r., sygn. akt I FSK 234/12, SIP Legalis nr 759936; wyrok WSA w Poznaniu z dnia 21 września 2011 r., sygn. akt I SA/Po 443/11, SIP Legalis nr 870821; wyrok WSA w Gdańsku z dnia 23 listopada 2011 r., sygn. akt I SA/Gd 1086/11, SIP Legalis nr 403404; wyrok WSA w Gorzowie Wielkopolskim z dnia 24 listopada 2011 r., sygn. akt I SA/Go 901/11, SIP Lex 1150062; wyrok WSA w Poznaniu z dnia 29 listopada 2011 r., sygn. akt I SA/Po
} 
również uwagę na to, że przyjęcie, iż dana osoba fizyczna - sprzedając grunty - działa jako handlowiec wymaga ustalenia, że jej czynności przybierają formę zorganizowaną i stałą ${ }^{38}$.

Po trzecie, zdaniem niektórych składów orzekających o prowadzeniu działalności gospodarczej świadczył sposób wykorzystywania nieruchomości przed jej sprzedażą, tj. fakt, że nieruchomość nie stanowiła majątku służącego zaspokajaniu osobistych potrzeb zbywcy, lecz była przedmiotem dzierżawy lub umów o podobnym charakterze ${ }^{39}$. Przesłanka ta nie była jednak postrzegana jako jednoznacznie przesądzająca o działaniu w charakterze podatnika. Naczelnemu Sądowi Administracyjnemu przyszło bowiem wyrażać pogląd, zgodnie z którym wykorzystywanie gruntów w sposób ciągły dla celów zarobkowych nie oznacza, że podmiot prowadzący działalność w rzeczonym zakresie nie ma możliwości wyłączenia ich $\mathrm{z}$ prowadzonej $\mathrm{w}$ ten sposób działalności i przeznaczenia na inne cele ${ }^{40}$.

660/11, SIP Legalis nr 428698; wyrok WSA w Olsztynie z dnia 30 listopada 2011 r., sygn. akt I SA/Ol 648/11, SIP Lex 1150375; wyrok WSA we Wrocławiu z dnia 20 grudnia 2011 r., sygn. akt I SA/Wr 1514/11, SIP Legalis nr 434155; wyrok WSA we Wrocławiu z dnia 19 stycznia 2012 r., sygn. akt I SA/Wr 1694/11, SIP Legalis nr 440598; wyrok WSA we Wrocławiu z dnia 23 stycznia 2012 r., sygn. akt I SA/Wr 1393/11, SIP Lex nr 1113492; wyrok WSA w Gliwicach z dnia 10 lutego 2012 r., sygn. akt III SA/G1 2042/11, SIP Lex nr 1139212; wyrok WSA w Szczecinie z dnia 15 lutego 2012 r., sygn. akt I SA/Sz 1002/11, SIP Legalis nr 474737; wyrok WSA we Wrocławiu z dnia 20 lutego 2012 r., sygn. akt I SA/Wr 1411/11, SIP Lex nr 1137377; wyrok NSA z dnia 21 lutego 2012 r., sygn. akt I FSK 1848/11, SIP Lex nr 1136181; wyrok WSA w Gliwicach z dnia 28 lutego 2012 r., sygn. akt III SA/G1 2033/11, SIP Lex nr 1139205; wyrok WSA we Wrocławiu z dnia 7 marca 2012 r., sygn. akt I SA/Wr 1469/11, SIP Legalis nr 488986; wyrok WSA w Szczecinie z dnia 7 marca 2012 r., sygn. akt I SA/Sz 1077/11, SIP Legalis 474800; wyrok WSA we Wrocławiu z dnia 20 marca 2012 r., sygn. akt I SA/Wr 195/12, CBOSA; wyrok WSA w Gdańsku z dnia 23 maja 2012 r., sygn. akt I SA/Gd 257/12, SIP Lex nr 1292469; wyrok WSA w Olsztynie z dnia 7 marca 2013 r., sygn. akt I SA/Ol 37/13, CBOSA; wyrok WSA w Olsztynie z dnia 28 marca 2013 r., sygn. akt I SA/Ol 82/13, SIP Lex nr 1299356; wyrok NSA z dnia 10 kwietnia 2013 r., sygn. akt I FSK 850/12, SIP Lex nr 1336093.

${ }^{38}$ Zob. wyrok NSA z dnia 21 lutego 2012 r., sygn. akt I FSK 1850/11, SIP Legalis nr 537896; wyrok NSA z dnia 24 lutego 2012 r., sygn. akt I FSK 1851/11, SIP Legalis nr 473691; wyrok WSA w Gorzowie Wielkopolskim z dnia 3 listopada 2011 r., sygn. akt I SA/Go 908/11, SIP Legalis 434104; wyrok WSA w Poznaniu z dnia 8 grudnia 2011 r., sygn. akt I SA/Po 514/11, SIP Legalis nr 422914; wyrok WSA we Wrocławiu z dnia 5 stycznia 2012 r., sygn. akt I SA/Wr 370/11, SIP Legalis nr 457603; wyrok WSA w Poznaniu z dnia 17 stycznia 2013 r., sygn. akt I SA/Po 847/12, SIP Legalis nr 558717.

${ }^{39}$ Zob. wyrok WSA w Gliwicach z dnia 16 maja 2007 r., sygn. akt III SA/Gl 218/07, SIP Lex nr 976408; wyrok WSA z dnia 1 grudnia 2011 r., sygn. akt I SA/Po 634/11, SIP Lex nr 1133507.

${ }^{40}$ Zob. wyrok NSA z dnia 5 kwietnia 2013 r., sygn. akt I FSK 752/12, SIP Lex nr 1336046. W tym aspekcie NSA wskazał również, że przyjęcie stanowiska odmiennego oznaczałoby, że 
Wskazując na przesłanki uzasadniające kwalifikację transakcji sprzedaży nieruchomości pod zabudowę jako czynności podlegającej opodatkowaniu VAT warto jeszcze zwrócić uwagę na dwie kwestie. Po pierwsze, w judykaturze petryfikacji uległo stanowisko, iż charakteru decydującego nie mają takie okoliczności, jak: sama liczba i zakres transakcji, dokonanie przez zbywcę podziału gruntu w celu osiągnięcia wyższej ceny, długość okresu, w jakim transakcje następowały czy wysokość osiągniętych z nich przychodów ${ }^{41}$. Po drugie, zgodnie $\mathrm{z}$ tezą sformułowaną przez Trybunał Sprawiedliwości w judykaturze wyrażano stanowisko, że dla rozstrzygnięcia kwestii powstania obowiązku podatkowego z tytułu sprzedaży nieruchomości przeznaczonych pod zabudowę nie ma znaczenia fakt, że sprzedawcy przysługiwał status rolnika ryczałtowego, jak również to, że grunty mające być przedmiotem sprzedaży zostały wydzielone z gospodarstwa rolnego ${ }^{42}$.

\section{KSZTAŁTOWANIE SIĘ LINII ORZECZNICZYCH PO NOWELIZACJI DEFINICJI LEGALNEJ DZIAŁALNOŚCI GOSPODARCZEJ}

W dniu 1 kwietnia 2013 r. weszły w życie przepisy ustawy nowelizującej ustawę o podatku od towarów i usług, w drodze których zmodyfikowano definicję legalną działalności gospodarczej, poprzez usunięcie zwrotu: „również wówczas, gdy czynność została wykonana jednorazowo w okolicznościach

\footnotetext{
sytuacja podmiotu prowadzącego działalność w rzeczonym zakresie byłaby gorsza od sytuacji rolnika dokonującego sprzedaży gruntu wykorzystywanego w działalności rolniczej.

${ }^{41}$ Zob. wyrok NSA z dnia 21 grudnia 2011 r., sygn. akt I FSK 1822/11, SIP Legalis nr 434150; wyrok NSA z dnia 10 stycznia 2012 r., sygn. akt I FSK 1697/11, SIP Legalis nr 491302; wyrok NSA z dnia 20 stycznia 2012 r., sygn. akt I FSK 1875/11, SIP Legalis nr 512218; wyrok NSA z dnia 26 stycznia 2012 r., sygn. akt I FSK 1707/11, SIP Legalis 466965; wyrok NSA z dnia 26 stycznia 2012 r., sygn. akt I FSK 1818/11, SIP Legalis nr 466959; wyrok NSA z dnia 31 stycznia 2012 r., sygn. akt I FSK 1667/11, SIP Legalis nr 531018; wyrok NSA z dnia 8 lutego 2012 r., sygn. akt I FSK 592/11, SIP Legalis nr 537967; wyrok NSA z dnia 16 lutego 2012 r., sygn. akt I FSK 1815/11, SIP Legalis nr 473866; wyrok NSA z dnia 21 lutego 2012 r., sygn. akt I FSK 1848/11, SIP Legalis nr 537894; wyrok NSA z dnia 29 lutego 2012 r., sygn. akt I FSK 1685/11, SIP Legalis nr 537823; wyrok NSA z dnia 21 września 2012 r., sygn. akt I FSK 1842/11, SIP Legalis nr552109; wyrok WSA we Wrocławiu z dnia 12 stycznia 2012 r., sygn. akt I SA/Wr 1537/11, SIP Legalis nr 457536; wyrok WSA w Szczecinie z dnia 10 maja 2012 r., sygn. akt I SA/Sz 214/12, SIP Legalis nr 486370.

${ }^{42}$ Zob. wyrok NSA z dnia 20 stycznia 2012 r., sygn. akt I FSK 1869/11, SIP Legalis nr 448324; wyrok NSA z dnia 8 lutego 2012 r., sygn. akt I FSK 1871/11, SIP Legalis nr 537969; wyrok NSA z dnia 14 czerwca 2012 r., sygn. akt I FSK 1453/11, SIP Lex nr 1216467; wyrok NSA z dnia 23 kwietnia 2013 r., sygn. akt I FSK 686/12, SIP Lex nr 1336020; wyrok WSA we Wrocławiu z dnia 15 grudnia 2011 r., sygn. akt I SA/Wr 1471/11, SIP Legalis nr 434123.
} 
wskazujących na zamiar wykonywania czynności w sposób częstotliwy". W konsekwencji, zgodnie z aktualnym brzmieniem ustawy, działalność gospodarcza obejmuje wszelką działalność producentów, handlowców lub usługodawców, w tym podmiotów pozyskujących zasoby naturalne oraz rolników, a także działalność osób wykonujących wolne zawody. Działalność gospodarcza obejmuje w szczególności czynności polegające na wykorzystywaniu towarów lub wartości niematerialnych i prawnych w sposób ciągły dla celów zarobkowych ${ }^{43}$. Wypada również zaznaczyć, że w drodze tej samej nowelizacji do ustawy o podatku od towarów i usług wprowadzono definicję legalną terenów budowlanych stanowiąc, że są to grunty przeznaczone pod zabudowę zgodnie z miejscowym planem zagospodarowania przestrzennego, a w przypadku braku takiego planu - zgodnie z decyzją o warunkach zabudowy i zagospodarowania terenu, o których mowa w przepisach o planowaniu i zagospodarowaniu przestrzennym ${ }^{44}$. W ocenie projektodawców modyfikacja definicji legalnej działalności gospodarczej miała służyć ściślejszemu odwzorowaniu przepisów Dyrektywy 2006/112/WE ${ }^{45}$, a także uwzględnieniu wniosków płynących z wyroku w sprawach C-180/10 i C-181/10. W tym aspekcie podkreślenia wymaga fakt, że zdaniem resortu finansów nowe brzmienie jednoznacznie wskazuje, że nie jest realizowana opcja uznania za podatnika każdego, kto dokonuje określonych transakcji związanych z działalnością gospodarczą w sposób okazjonalny. Z kolei celem wprowadzenia definicji terenów budowlanych było ułatwienie podatnikom stosowania przepisów dotyczących zwolnienia z VAT poprzez usunięcie rozbieżności pomiędzy organami podatkowymi a sądami administracyjnymi w kwestii elementów decydujących o budowlanym charakterze danego terenu w przypadku, gdy nie został wydany dla tego terenu plan zagospodarowania przestrzennego ${ }^{46}$.

Wskazana nowelizacja niewątpliwie zasługuje na aprobatę. Niemniej jednak kwestia kwalifikacji prawnopodatkowej czynności dostawy działek wydzielonych w wyniku podziału nieruchomości rolnej w dalszym ciągu stanowi przedmiot licznych wątpliwości w praktyce gospodarczej. Przegląd orzecz-

\footnotetext{
${ }^{43}$ Art. 15 ust. 2 ustawy o podatku od towarów i usług w brzmieniu nadanym ustawą z dnia 7 grudnia 2012 r. o zmianie ustawy o podatku od towarów i usług oraz niektórych innych ustaw, Dz. U. poz. 35.

${ }^{44}$ Art. 2 pkt 33 ustawy o podatku od towarów i usług.

${ }^{45}$ Dyrektywa 2006/112/WE z dnia 28 listopada 2006 r. w sprawie wspólnego systemu podatku od wartości dodanej, Dz.U. L 347 z 11.12.2006, str. 1-118, dalej jako: Dyrektywa 2006/112/WE.

${ }^{46}$ Zob. uzasadnienie do rządowego projektu ustawy o zmianie ustawy o podatku od towarów i usług oraz o zmianie niektórych innych ustaw, druk sejmowy nr 805, Sejm VII kadencji, s. 9 i 15.
} 
nictwa prowadzi do konkluzji, że w ostatnich latach zdecydowanie wyraźniej akcentowany jest fakt, że dla oceny, czy dany podmiot działa w charakterze podatnika VAT, nie ma znaczenia to, w jaki sposób i z jakim zamiarem nabywał grunty. Istotny jest bowiem sposób postępowania w okresie późniejszym, poprzedzającym sprzedaż ${ }^{47}$. Możliwa jest zatem sytuacja, w której nabycie działki następuje dla celów prywatnych, a następnie właściciel zmienia przeznaczenie gruntów i działa w sposób typowy dla handlowca, co uzasadnia objęcie czynności sprzedaży opodatkowaniem ${ }^{48}$. W orzecznictwie sądów administracyjnych zmianie nie ulega natomiast stanowisko, że niektóre z czynności podejmowanych przez właścicieli nieruchomości, w tym również rolników, mogą wskazywać, że aktywność sprzedającego przybiera formę profesjonalną. Do czynności tych zalicza się m.in.: uzyskiwanie decyzji o warunkach zabudowy budynkami mieszkalnymi, uzbrojenie terenu, wydzielenie dróg wewnętrznych, nakłady inwestycyjne wykraczające poza standardowy zarząd majątkiem prywatnym oraz działania marketingowe podjęte w celu sprzedaży działek, wykraczające poza zwykłe formy ogłoszenia. Oczywiście aktywności te winny być oceniane w ich całokształcie, a nie w kontekście pojedynczych czynności ${ }^{49}$. Istotne jest również ustalenie, że

\footnotetext{
${ }^{47}$ Zob. wyrok NSA z dnia 29 sierpnia 2014 r., sygn. akt I FSK 1229/13, SIP Legalis nr 1092078; wyrok NSA z dnia 1 lipca 2016 r., sygn. akt I FSK 94/15, SIP Lex nr 2118032; wyrok NSA z dnia 4 kwietnia 2017 r., sygn. akt I FSK 1855/15, SIP Lex nr 2301560; wyrok NSA z dnia 10 maja 2017 r., sygn. akt I FSK 1639/15, SIP Lex nr 2315482; wyrok NSA z dnia 5 października 2017 r., sygn. akt I FSK 188/16, SIP Legalis nr 1694822; wyrok NSA z dnia 5 czerwca 2019 r., sygn. akt I FSK 983/17, SIP Lex nr 2696204; wyrok WSA w Warszawie z dnia 14 marca 2017 r., sygn. akt III SA/Wa 401/16, SIP Lex nr 2289985; wyrok WSA w Gdańsku z dnia 12 września 2017 r., sygn. akt I SA/Gd 884/17, SIP Lex nr 2366602; wyrok WSA w Lodzi z dnia 24 kwietnia 2018 r., sygn. akt I SA/Łd 184/18, SIP Lex nr 2493752; wyrok WSA w Łodzi z dnia 19 czerwca 2018 r., sygn. akt I SA/Łd 296/18, SIP Lex nr 2510423.

${ }^{48}$ Zob. wyrok NSA z dnia 19 lutego 2016 r., sygn. akt I FSK 1381/14, SIP Lex nr 2035413; wyrok NSA z dnia 7 lutego 2017 r., sygn. akt I FSK 1022/15, SIP Lex nr 1578828; wyrok NSA z dnia 6 lipca 2018 r., sygn. akt I FSK 1716/16, SIP Lex nr 2523561; wyrok NSA z dnia 6 lipca 2018 r., sygn. akt I FSK 1986/16, SIP Lex nr 252364; wyrok WSA w Szczecinie z dnia 5 maja 2016 r., sygn. akt I SA/Sz 141/16, SIP Lex nr 2097983.

${ }^{49}$ Zob. np.: wyrok NSA z dnia 17 stycznia 2013 r., sygn. akt I FSK 239/12, SIP Lex nr 1360651; wyrok NSA z dnia 29 kwietnia 2014 r., sygn. akt I FSK 621/13, SIP Lex nr 1480690; wyrok NSA z dnia 6 listopada 2014 r., sygn. akt I FSK 1684/13, SIP Lex nr 1590729; wyrok NSA z dnia 3 marca 2015 r., sygn. akt I FSK 1859/13, SIP Lex nr 1651672; wyrok NSA z dnia 11 czerwca 2015 r., sygn. akt I FSK 716/14, SIP Lex nr 1772904; wyrok NSA z dnia 13 lipca 2016 r., sygn. akt I FSK 101/15, SIP Lex nr 2100263; wyrok NSA z dnia 17 stycznia 2017 r., sygn. akt I FSK 1031/15, SIP Lex nr 2271929; wyrok NSA z dnia 15 lutego 2017 r., sygn. akt I FSK 902/15, SIP Lex nr 2271890; wyrok NSA z dnia 3 marca 2017 r., sygn. akt I FSK 1150/15, SIP Lex nr 2282067; wyrok NSA z dnia 17 marca 2017 r., sygn. akt I FSK 1643/15, SIP Lex nr 2316575; wyrok NSA z dnia 5 kwietnia 2017 r., sygn. akt I FSK 1423/15, SIP Lex nr 2296441;
} 
działalność osoby fizycznej w zakresie sprzedaży działek budowlanych przybierała postać profesjonalną, stałą (powtarzalną, z zamiarem jej kontynuowania) oraz zorganizowaną ${ }^{50}$. Tym samym, sama liczba transakcji, długość okresu, w którym są one dokonywane, wysokość przychodów osiągniętych z tytułu sprzedaży działek czy subiektywne przekonanie i ocena zbywcy co do charakteru transakcji nie są decydujące dla uznania sprzedawcy za podatnika $\mathrm{VAT}^{51}$. Co istotne, w najnowszym orzecznictwie zdecydowanie wyraźniej akcentowana jest teza, zgodnie z którą każda osoba należycie dbająca o własne interesy czyni to w sposób zapewniający jej osiągnięcie maksymalnych korzyści, niezależnie od tego, czy dysponuje majątkiem przeznaczonym do

wyrok NSA z dnia 20 kwietnia 2017 r., sygn. akt I FSK 1895/15, SIP Lex nr 2299814; wyrok WSA w Szczecinie z dnia 21 stycznia 2016 r., sygn. akt I SA/Sz 1284/15, SIP Lex nr 1996001; wyrok WSA w Gliwicach z dnia 4 kwietnia 2016 r., sygn. akt III SA/Gl 1136/15, SIP Lex nr 2046269; wyrok WSA we Wrocławiu z dnia 6 kwietnia 2017 r., sygn. akt I SA/Wr 1429/16, SIP Lex nr 2301536; wyrok WSA w Bydgoszczy z dnia 12 kwietnia 2016 r., sygn. akt I SA/Bd 81/16, SIP Lex nr 2049845; wyrok WSA w Warszawie z dnia 14 kwietnia 2016 r., sygn. akt VIII SA/Wa 937/15, SIP Lex nr 2056095; wyrok WSA w Szczecinie z dnia 3 sierpnia 2016 r., sygn. akt I SA/Sz 617/16, SIP Lex nr 2116060; wyrok WSA w Poznaniu z dnia 1 września 2016 r., sygn. akt I SA/Po 1765/15, SIP Lex nr 2122705; wyrok WSA w Gdańsku z dnia 19 października 2016 r., sygn. akt I SA/Gd 692/16, SIP Lex nr 2153760; wyrok WSA w Szczecinie z dnia 29 marca 2017 r., sygn. akt I SA/Sz 89/17, SIP Lex nr 2279301; wyrok WSA we Wrocławiu z dnia 6 kwietnia 2017 r., sygn. akt I SA/Wr 1429/16, SIP Lex nr 2301536; wyrok WSA w Kielcach z dnia 12 kwietnia 2017 r., sygn. akt I SA/Ke 110/17, SIP Lex nr 2279208; wyrok WSA w Gliwicach z dnia 21 czerwca 2017 r., sygn. akt III SA/G1 321/17, SIP Lex nr 2338534; wyrok WSA w Łodzi z dnia 24 kwietnia 2018 r., sygn. akt I SA/Łd 146/18, SIP Lex nr 2493722; wyrok WSA w Gdańsku z dnia 23 października 2018 r., sygn. akt I SA/Gd 844/18, SIP Lex nr 2580847; wyrok WSA w Gliwicach z dnia 23 maja 2019 r., sygn. akt I SA/Gl 412/19, SIP Lex nr 2687936.

${ }^{50}$ Zob. wyrok NSA z dnia 5 kwietnia 2018 r., sygn. akt II FSK 2411/17, SIP Lex nr 253358; wyrok WSA w Olsztynie z dnia 13 stycznia 2016 r., sygn. akt I SA/Ol 680/15, SIP Lex nr 1998589; wyrok WSA w Szczecinie z dnia 11 maja 2016 r., sygn. akt I SA/Sz 127/16, SIP Lex nr 2097968; wyrok WSA w Szczecinie z dnia 16 czerwca 2016 r., sygn. akt I SA/Sz 422/16, SIP Lex nr 2098163; wyrok WSA w Lublinie z dnia 15 lutego 2017 r., sygn. akt I SA/Lu 701/16, SIP Lex nr 2275351; wyrok WSA w Bydgoszczy z dnia 13 czerwca 2017 r., sygn. akt I SA/Bd 305/17, SIP Lex nr 2325243; wyrok WSA w Gliwicach z dnia 18 lipca 2017 r., sygn. akt III SA/G1 551/17, SIP Lex nr 2340872; wyrok WSA w Gorzowie Wielkopolskim z dnia 18 kwietnia 2018 r., sygn. akt I SA/Go 50/18, SIP Lex nr 2485818. Analogiczne stanowisko wyrażano w doktrynie. Zob. J. BUDZISZEWSKI, Odpłatne zbycie udziałów w nieruchomościach a status podatnika podatku od towarów i ustug, „Doradztwo Podatkowe” (2015), nr 7, s. 37.

${ }^{51}$ Zob. wyrok NSA z dnia 22 listopada 2017 r., sygn. akt I FSK 2306/15, SIP Legalis nr1726459; wyrok WSA w Łodzi z dnia 22 listopada 2016 r., sygn. akt I SA/Łd 904/16, SIP Lex nr 2175653; wyrok NSA z dnia 21 lutego 2017 r., sygn. akt II FSK 47/15, SIP Lex nr 2291022; wyrok WSA w Łodzi z dnia 2 marca 2017 r., sygn. akt I SA/Łd 17/17, SIP Lex nr 2261443; wyrok WSA w Łodzi z dnia 7 marca 2017 r., sygn. akt I SA/Łd 16/17, SIP Lex nr 2254343; wyrok WSA w Szczecinie z dnia 24 maja 2017 r., sygn. akt I SA/Sz 320/17, SIP Lex nr 2314835. 
prowadzenia działalności gospodarczej, czy służącym celom osobistym ${ }^{52}$. W konsekwencji okoliczność, że dana osoba fizyczna wystąpiła o wydanie decyzji o ustaleniu warunków zabudowy, scalenie, a następnie podział gruntów, nie przesądza automatycznie o nabyciu statusu podatnika $\mathrm{VAT}^{53}$. Jednocześnie w judykaturze konsekwentnie wyrażany jest pogląd, że o ile sama ilość dokonywanych transakcji nie jest czynnikiem samodzielnie przesądzającym o uznaniu danego podmiotu za podatnika, o tyle w korelacji z innymi okolicznościami może uzasadniać konkluzję, że konkretna czynność wykraczała poza zakres zwykłego wykonywania prawa własności ${ }^{54}$. Warto również zaznaczyć, że w orzecznictwie wyrażono stanowisko, że dla określenia, czy w konkretnym przypadku mamy do czynienia $\mathrm{z}$ działalnością, która nosi cechy działalności gospodarczej w rozumieniu ustawy o podatku od towarów i usług, nie ma konieczności bezpośredniego porównywania środków angażowanych przez przedsiębiorców prowadzących działalność gospodarczą. Jest bowiem rzeczą oczywistą, że takie same działania (np. doprowadzenie do zmiany planu zagospodarowania przestrzennego, dokonanie podziału geodezyjnego czy uzbrojenie działek) będą na tym samym obszarze oznaczały podobne zaangażowanie środków bez względu na podmiot, który je ponosi ${ }^{55}$.

W judykaturze petryfikacji uległ pogląd, że o prowadzeniu działalności gospodarczej świadczy sposób wykorzystywania nieruchomości przed jej sprzedażą, czyli np. jej dzierżawa, która w świetle przepisów o podatku od towarów i usług stanowi odpłatne świadczenie usług. Przyjmuje się bowiem, że jeżeli osoba dokonuje dostawy gruntu, przy pomocy którego prowadziła wcześniej nieprzerwanie działalność gospodarczą, to czyni to w ramach prowadzonej działalności, a nie zarządu majątkiem własnym ${ }^{56}$. Oczywiście nie

\footnotetext{
${ }^{52}$ Zob. wyrok WSA w Gliwicach z dnia 7 marca 2018 r., sygn. akt III SA/Gl 1016/17, SIP Lex nr 2470620; wyrok WSA w Bydgoszczy z dnia 17 września 2019 r., sygn. akt I SA/Bd 194/19, SIP Lex nr 2724423.

${ }^{53}$ Tamże. Zob. także wyrok WSA w Bydgoszczy z dnia 20 czerwca 2017 r., sygn. akt I SA/Bd 540/17, SIP Legalis nr 1629780; wyrok WSA w Szczecinie z dnia 11 kwietnia 2018 r., I SA/Sz 120/18, SIP Lex nr 2475285; wyrok WSA w Szczecinie z dnia 6 grudnia 2018 r., sygn. akt I SA/Sz 689/18, SIP Lex nr 2604611; wyrok WSA w Poznaniu z dnia 30 stycznia 2019 r., sygn. akt I SA/Po 893/18, SIP Lex nr 2621345; wyrok WSA w Krakowie z dnia 25 września 2019 r., sygn. akt I SA/Kr 515/19, SIP Lex nr 2734320.

${ }^{54}$ Zob. wyrok NSA z dnia 3 grudnia 2014 r., sygn. akt I FSK 1845/13, SIP Lex nr 1646143; wyrok NSA z dnia 8 marca 2017 r., sygn. akt I FSK 1268/15, SIP Lex nr 2276056; wyrok WSA w Łodzi z dnia 20 czerwca 2018 r., sygn. akt I SA/Ld 294/18, SIP Lex nr 2520235.

${ }^{55}$ Zob. wyrok WSA w Szczecinie z dnia 16 listopada 2016 r., sygn. akt I SA/Sz 966/16, SIP Lex nr 2183019.

${ }^{56}$ Zob. wyrok NSA z dnia 1 października 2013 r., sygn. akt I FSK 1414/12, SIP Legalis nr 738401; wyrok NSA z dnia 3 marca 2015 r., sygn. akt I FSK 601/14, SIP Lex nr 1666058; wyrok
} 
oznacza to, że podmiot wykorzystujący części nieruchomości w celach zarobkowych nie może dokonywać takich czynności w ramach wykonywania swojego prawa własności w sposób przynoszący zyski w jego majątku osobistym. Wykonywanie tego prawa należy zawsze oceniać przy uwzględnieniu kryteriów wskazanych w powołanym wyroku Trybunału Sprawiedliwości Unii Europejskiej ${ }^{57}$.

Stanowisko, w myśl którego uprzednie wykorzystywanie nieruchomości do celów działalności gospodarczej przesądza o kwalifikacji transakcji sprzedaży tej nieruchomości jako podlegającej opodatkowaniu VAT, ma istotne znaczenie dla rolników. Analiza treści interpretacji podatkowych jednoznacznie wskazuje bowiem na to, że w sytuacji, gdy sprzedaży dokonuje osoba fizyczna zarejestrowana jako czynny podatnik VAT z tytułu prowadzenia działalności rolniczej, a przedmiot sprzedaży stanowią działki wydzielone $\mathrm{z}$ nieruchomości wykorzystywanych uprzednio do prowadzenia tego rodzaju działalności, czynność ta jest traktowana jako wykonywana w ramach działalności gospodarczej. Symptomatyczny jest przy tym fakt, że w przypadku sprzedaży przez czynnego podatnika VAT ocenie nie podlega to, czy sprzedawca podejmuje aktywne działania w zakresie obrotu nieruchomościami. W ocenie organów podatkowych okolicznością przesądzającą o opodatkowaniu jest bowiem kwalifikacja nieruchomości jako składnika majątkowego służącego prowadzeniu działalności gospodarczej. Nie ma przy tym znaczenia fakt, że grunty stanowiące przedmiot transakcji nie są w momencie sprzedaży wykorzystywane w działalności gospodarczej, jak również to, że działalność polegająca na obrocie ziemią nie mieści się w pojęciu

NSA z dnia 10 kwietnia 2015 r., sygn. akt I FSK 367/14, SIP Lex nr 1771770; wyrok NSA z dnia 22 kwietnia 2016 r., sygn. akt I FSK 1748/14, SIP Legalis nr 1470236; wyrok WSA w Opolu z dnia 7 lipca 2016 r., sygn. akt I SA/Op 230/16, SIP Lex nr 2086421; wyrok WSA we Wrocławiu z dnia 19 stycznia 2017 r., I SA/Wr 1181/16, SIP Legalis nr 1603508; wyrok WSA w Warszawie z dnia 29 maja 2018 r., sygn. akt III SA/Wa 3933/17, SIP Lex nr 2575310. Sądom administracyjnym przyszło również wyrażać pogląd, że w sytuacji wygaśnięcia umowy dzierżawy nie można mówić o prowadzeniu działalności gospodarczej, co oznacza, że sprzedaż dotyczy majątku prywatnego. Zob. wyrok WSA we Wrocławiu z dnia 18 stycznia 2017 r., sygn. akt I SA/Wr 1027/16, SIP Legalis nr 1575595.

${ }^{57}$ Zob. wyrok NSA z dnia 5 kwietnia 2013 r., sygn. akt I FSK 752/12; wyrok WSA w Warszawie z dnia 12 czerwca 2015 r., sygn. akt III SA/Wa 3193/14, SIP Lex nr 1730207; wyrok WSA we Wrocławiu z dnia 18 stycznia 2017 r., sygn. akt I SA/Wr 1027/16, CBOSA; wyrok WSA w Gliwicach z dnia 14 listopada 2017 r., sygn. akt III SA/G1 704/17, CBOSA; wyrok WSA w Gliwicach z dnia 15 listopada 2017 r., sygn. akt III SA/Gl 705/17, CBOSA; wyrok WSA w Bydgoszczy z dnia 8 maja 2019 r., sygn. akt I SA/Bd 190/19, SIP Lex nr 2684542. 
działalności rolniczej ${ }^{58}$. Uzasadniając powyższą tezę podnosi się, że warunkiem zaliczenia nieruchomości do majątku prywatnego, a w konsekwencji uznania transakcji za niepodlegającą opodatkowaniu VAT, jest wykazywanie zamiaru wykorzystywania tej nieruchomości w ramach majątku osobistego przez cały okres jej posiadania ${ }^{59}$. Powyższe stanowisko jest również reprezentowane w judykaturze. W wyroku z dnia 26 października 2016 r. Naczelny Sąd Administracyjny orzekł, że w sytuacji w której strona zamierza dokonać dostawy gruntu, przy pomocy którego prowadziła działalność rolniczą, nie czyni tego $\mathrm{w}$ ramach zarządu majątkiem osobistym ${ }^{60}$. W orzecznictwie wyrażano także pogląd, że warunkiem uznania transakcji za niepodlegającą opodatkowaniu VAT jest wykazywanie zamiaru wykorzystywania części nieruchomości w ramach majątku osobistego przez cały okres jej posiadania ${ }^{61}$. Niemniej jednak należy zaznaczyć, że w powyższej kwestii podejmowano także odmienne rozstrzygnięcia ${ }^{62}$. Z kolei w sytuacji, gdy odpłatnego zbycia nieruchomości dokonuje rolnik ryczałtowy lub osoba prowadząca gospodarstwo rolne wyłącznie na własne potrzeby, zarówno w orzecznictwie sądowym, jak i organów podatkowych jednomyślnie przyjmuje się, że warunkiem opodatkowania transakcji jest stwierdzenie, że zbywca podejmuje

\footnotetext{
${ }^{58}$ Zob. np.: pismo Dyrektora Krajowej Informacji Skarbowej z dnia 21 czerwca 2017 r., sygn. 0112-KDIL2-2.4012.29.2017.2.IP, SIP Lex nr 351619; pismo Dyrektora Krajowej Informacji Skarbowej z dnia 12 lipca 2017 r., sygn. 0112-KDIL1-1.4012.97.2017.2.RW, SIP Lex nr 352883; pismo Dyrektora Krajowej Informacji Skarbowej z dnia 19 czerwca 2017 r., sygn. 0112-KDIL23.4012.106.2017.2.BC, SIP Lex nr 352331; pismo Dyrektora Krajowej Informacji Skarbowej z dnia 12 czerwca 2017 r., sygn. 0114-KDIP1-1.4012.84.2017.2.RR, SIP Lex nr 350934; pismo Dyrektor Krajowej Informacji Skarbowej z dnia 1 marca 2019 r., sygn. 0115-KDIT1-3/4012. 19.2019.1.APR; pismo Dyrektor Krajowej Informacji Skarbowej z dnia 4 kwietnia 2019 r., sygn. 0112-KDIL1-3.4012.32.2019.2.AP; pismo Dyrektor Krajowej Informacji Skarbowej z dnia 7 maja 2019 r., sygn.0112-KDIL1-2.4012.99.2019.2.TK; pismo Dyrektor Krajowej Informacji Skarbowej z dnia 13 maja 2019 r., sygn. 0115-KDIT1-3.4012.176.2019.2.BJ; pismo Dyrektor Krajowej Informacji Skarbowej z dnia 29 października 2019 r., sygn. 0115-KDIT1-2.4012.492.2019.2.DM.

${ }^{59} \mathrm{~W}$ ocenie organów podatków powyższa konkluzja wynika z treści wyroku TSUE z dnia 4 października 1995 r., w sprawie C-291/92 Finanzamt Uelzen v. Dieter Armbrecht, ECLI:EU:C: 1995:304.

${ }^{60}$ Zob. wyrok NSA z dnia 26 października 2016 r., sygn. akt I FSK 246/15.

${ }^{61}$ Zob. wyrok WSA w Poznaniu z dnia 8 listopada 2017 r., sygn. akt I SA/Po 501/17, SIP Lex nr 2400; wyrok WSA w Olsztynie z dnia 11 czerwca 2019 r., sygn. akt I SA/Ol 248/19, SIP Lex nr 2700755. Na konieczność spełnienia powyższej przesłanki zwraca się również w doktrynie. Zob. T. JANICKI, N. KociaK, Zbycie nieruchomości - skutki podatkowe w VAT, „Przegląd Podatkowy" (2019), nr 7, s. 11-12.

${ }^{62}$ Zob. wyrok WSA w Poznaniu z dnia 30 stycznia 2019 r., sygn. akt I SA/Po 893/18, SIP Legalis nr 1875905.
} 
aktywne działania w zakresie obrotu nieruchomościami, angażując środki podobne do wykorzystywanych przez handlowców ${ }^{63}$.

\section{KONKLUZJE}

Pomimo wyrażanych w przestrzeni publicznej oczekiwań rolników dotyczących zmian legislacyjnych, które pozwoliłyby na jednoznaczne i wyraźne określenie konsekwencji prawnopodatkowych sprzedaży nieruchomości pod zabudowę, zmiana tego rodzaju nie została wprowadzona. Przyczyn takiego stanu rzeczy należy upatrywać w tym, że w świetle kluczowych zasad systemu podatku od wartości dodanej nie jest możliwe sformułowanie przepisu, który pozwalałby na skuteczne zweryfikowanie każdego przypadku w kontekście tego, czy zbywający działa jako podatnik, czy jako osoba wykonująca prawo własności. Stwierdzenie, czy dany podmiot, w odniesieniu do konkretnej czynności, działa jako podatnik VAT, wymaga każdorazowo oceny dokonanej na gruncie stanu faktycznego konkretnej sprawy. Wydaje się, że powyższa okoliczność przesądziła również o tym, iż pomimo zapowiedzi resortu finansów nie została wydana interpretacja ogólna dotycząca rzeczonego zagadnienia ${ }^{64}$. Nieograniczone bogactwo stanów faktycznych nie pozwala bowiem na stworzenie modelowego rozwiązania, mającego zastosowanie w każdym przypadku.

\footnotetext{
${ }^{63}$ Zob. np.: pismo Dyrektora Krajowej Informacji Skarbowej z dnia 15 marca 2018 r., sygn. 0115-KDIT1-2.4012.40.2018.2.RS; pismo Dyrektor Krajowej Administracji Skarbowej z dnia 2 lipca 2018 r., sygn. 0115-KDIT1-2.4012.438.2018.1.RS; pismo Dyrektor Krajowej Administracji Skarbowej z dnia 1 października 2018 r., sygn. 0112-KDIL2-1.4012.391.2018.2.AS; pismo Dyrektor Krajowej Administracji Skarbowej z dnia 29 sierpnia 2019 r., sygn. 0112-KDIL4.4012. 317.2019.1.EB; pismo Dyrektor Krajowej Administracji Skarbowej z dnia 21 października 2019 r., sygn. 0112-KDIL1-3.4012.437.2019.2.AKS; pismo Dyrektor Krajowej Administracji Skarbowej z dnia 4 listopada 2019 r., sygn. 0115-KDIT1-2.4012.483.2019.2.PS; pismo Dyrektor Krajowej Administracji Skarbowej z dnia 5 listopada 2019 r., sygn. 0113-KDIPT1-3.4012.509.2.EG; pismo Dyrektor Krajowej Administracji Skarbowej z dnia 8 listopada 2019 r., sygn. 0114-KDIP12.4012.488.2019.2.WH; pismo Dyrektor Krajowej Administracji Skarbowej z dnia 8 listopada 2019 r., sygn. 0112-KDIL1-3.4012.451.2019.2.AP; pismo Dyrektor Krajowej Administracji Skarbowej z dnia 8 listopada 2019 r., sygn. 0111-KDIB3-1.4012.563.2019.2.MSO, http://sip.mf.gov. pl.

${ }^{64}$ Wydanie takiej interpretacji zapowiedział podsekretarz stanu w Ministerstwie Finansów Paweł Gruza. Zob. odpowiedź na interpelację nr 15866 w sprawie wykładni przepisów ustawy o podatku od towarów i usług w zakresie sprzedaży gruntów rolnych, Sejm VIII kadencji, http://www.sejm.gov.pl/sejm8.nsf/interpelacja.xsp?documentId=E9AA9F950154D9D5C12581A 900370FFF [dostęp: 2.10.2018].
} 
Z przeprowadzonej analizy wynika, że dorobek judykatury odnoszący się do opodatkowania VAT sprzedaży działek pod zabudowę jest niezmiernie bogaty, a także zróżnicowany. Na przestrzeni lat następowały zmiany linii orzeczniczych dotyczących następujących kwestii.

Po pierwsze, wyrażano odmienne oceny na temat tego, czy Polska skorzystała $\mathrm{z}$ przewidzianej $\mathrm{w}$ przepisach prawa unijnego możliwości uznania za podatnika każdego, kto okazjonalnie zawiera transakcje związane z działalnością gospodarczą. W pierwszych latach obowiązywania ustawy o podatku od towarów i usług dominowało stanowisko, że w powyższym zakresie dokonano transpozycji przepisów dyrektywy, przy czym realizacja owej opcji nastąpiła $\mathrm{w}$ sposób wysoce niedoskonały, tj. poprzez rozszerzenie definicji legalnej działalności gospodarczej. Po wydaniu przez Trybunał Sprawiedliwości orzeczenia w sprawach połączonych C-180/10 i C-181/10 zaczęła się kształtować linia orzecznicza, w myśl której w ustawie o podatku od towarów i usług brak było takiego jednoznacznego i precyzyjnego unormowania, z którego wynikałoby, że Polska skorzystała z uprawnienia do opodatkowania okazjonalnych transakcji.

Po drugie, na tle definicji legalnej działalności gospodarczej w brzmieniu obowiązującym do 31 marca 2013 r. wyrażano stanowisko, że z uwagi na powtarzalność transakcji sam fakt dokonywania sprzedaży podzielonej na działki nieruchomości gruntowej przesądza o prowadzeniu przez sprzedającego działalności gospodarczej. Należy jednak podkreślić, że w odniesieniu do powyższej kwestii już w 2007 r. nastąpiła zmiana linii orzeczniczej. W konsekwencji jeszcze przed nowelizacją definicji legalnej petryfikacji uległ pogląd, że do przyjęcia opodatkowania danej czynności VAT nie wystarcza sam fakt wykonania czynności mieszczącej się w zakresie przedmiotowym podatku, lecz czynność ta winna być dokonana przez podatnika, a w sytuacjach dotyczących sprzedaży działek najczęściej handlowca prowadzącego samodzielnie działalność gospodarczą.

Po trzecie, zmianom ulegały stanowiska sądów dotyczące poszczególnych przesłanek wskazujących na to, że sprzedając nieruchomości pod zabudowę, dana osoba fizyczna działa w charakterze podatnika VAT. I tak, o ile do czasu nowelizacji definicji legalnej działalności gospodarczej wyrażano rozbieżne oceny na temat tego, czy dla kwalifikacji prawnopodatkowej czynności sprzedaży jako podlegającej opodatkowaniu konieczne było jej nabycie w celu odsprzedaży, o tyle w ostatnich latach zdecydowanie przeważa stanowisko, że okoliczność ta nie jest prawnie relewantna. Analogicznym zmianom uległy poglądy judykatury na temat przesłanki, jaką jest przeznaczenie 
środków uzyskanych ze sprzedaży nieruchomości na cele osobiste lub działalności gospodarczej. W orzecznictwie ukształtowała się również linia orzecznicza odnosząca się do oceny sytuacji, w której zbywana nieruchomość stanowiła uprzednio przedmiot dzierżawy lub umów o podobnym charakterze. Większość składów orzekających zajmuje bowiem stanowisko, że w przypadku sprzedaży nieruchomości wykorzystywanych uprzednio do prowadzenia tego rodzaju działalności czynność ta jest traktowana jako wykonywana w ramach działalności gospodarczej.

Po czwarte, w praktyce gospodarczej liczne wątpliwości rodzą sytuacje, w których sprzedaży dokonuje osoba fizyczna zarejestrowana jako czynny podatnik VAT z tytułu prowadzenia działalności rolniczej, a przedmiot sprzedaży stanowią działki wydzielone $\mathrm{z}$ nieruchomości wykorzystywanych uprzednio do prowadzenia tego rodzaju działalności. W orzecznictwie brak jest jednolitości stanowisk w powyższej materii. Naczelnemu Sądowi Administracyjnemu przyszło jednak wyrażać pogląd, w myśl którego, jeżeli osoba prowadząca działalność rolniczą zamierza dokonać dostawy gruntu, przy pomocy którego prowadziła działalność rolniczą, nie czyni tego w ramach zarządu majątkiem osobistym.

Po piąte, w odniesieniu do osób fizycznych, które prowadzą gospodarstwo rolne wyłącznie na własne potrzeby, jak również rolników prowadzących działalność rolniczą w rozumieniu ustawy o podatku od towarów i usług, lecz korzystających ze zwolnienia dla rolników ryczałtowych, w judykaturze jednomyślnie przyjmuje się, iż warunkiem opodatkowania transakcji jest stwierdzenie, że zbywca podejmuje aktywne działania w zakresie obrotu nieruchomościami. W orzecznictwie wypracowano przy tym szereg wskazówek dotyczących tego, jakie czynności podejmowane przez właścicieli nieruchomości mogą świadczyć o tym, że aktywność sprzedającego przybiera postać profesjonalną. Można zatem uznać, że owa linia orzecznicza, jako utrwalona i upowszechniona, w odniesieniu do powyższej kwestii w sposób wyraźny wyznacza treść przepisu ustawy o podatku od towarów i usług definiującego pojęcie działalności gospodarczej.

BIBLIOGRAFIA

ŹRÓDŁA PRAWA

Dyrektywa 2006/112/WE z dnia 28 listopada 2006 r. w sprawie wspólnego systemu podatku od wartości dodanej, Dz.U. L 347 z 11.12.2006, str. 1-118. 
Ustawa z dnia 11 marca 2004 r. o podatku od towarów i usług, tekst jedn. Dz. U. 2018 poz. 2174, z późn. $z m$.

Ustawa z dnia 7 grudnia 2012 r. o zmianie ustawy o podatku od towarów i usług oraz niektórych innych ustaw, Dz. U. poz. 35.

\section{LITERATURA}

BUDZISZEWSKI Jacek: Odpłatne zbycie udziałów w nieruchomościach a status podatnika podatku od towarów i usług, „Doradztwo Podatkowe” (2015), nr 7, s. 35-37.

DoMINIK Dagmara: Czy sprzedaż działki budowlanej przez rolnika jest opodatkowana VAT?, „Jurysdykcja Podatkowa” (2008), nr 6, s. 26-32.

JANICKI Tomasz, KociaK Natalia: Zbycie nieruchomości - skutki podatkowe w VAT, „Przegląd Podatkowy" (2019), nr 7, s. 11-13.

KARWACKI Przemysław, KosaKowSKa Katarzyna: Sprzedaż nieruchomości gruntowych przez osoby fizyczne nieprowadzące działalności gospodarczej. Glosa do wyroku NSA z dnia 24 kwietnia 2007 r., I FSK 603/06 oraz do wyroków WSA z dnia 26 stycznia 2007 r., I SA/Wr 1688/06 i z dnia 21 lutego 2007 r., III SA/Wa 4176/06, „Prawo i Podatki” (2011), nr 15, s. 17-18.

LASIŃSKI-SULECKI Krzysztof: Glosa do wyroku NSA z dnia 24 kwietnia 2007 r., sygn. akt I FSK 603/2006, SIP Lex.

MARCZUK Bartosz: Rolnik zabił się, bo nie wytrzymał starcia z urzędnikami, „Rzeczpospolita” $\mathrm{z}$ dnia 25.06.2013 r.

MATUSIAKIEWICZ Łukasz: VAT od działek sprzedawanych przez rolników ryczałtowych - wątpliwości pozostają, „Nieruchomości” (2011), nr 12, SIP Legalis.

MiLliTz Małgorzata: Sprzedaż działek budowlanych z majątku niezwiązanego z działalnością gospodarczą. Glosa do wyroku NSA z dnia 29 października 2007 r., I FPS 3/07, „Przegląd Podatkowy" (2008), nr 2, s. 42-47.

ORŁOWSKI Janusz: Dostawa terenów budowlanych oraz przeznaczonych pod zabudowę, w: Wykładnia i stosowanie prawa podatkowego. Węzłowe problemy, red. B. Brzeziński, SIP Lex/el. 2013.

WesoŁowsKa Agnieszka: Glosa do wyroku TS z dnia 15 września 2011 r., C-180/10 i C-181/10, SIP Lex.

ŻARKOWSKA Anna: Sprzedaż niezabudowanych działek wykorzystywanych rolniczo nie podlega opodatkowaniu podatkiem od towarów i usług, „Doradztwo Podatkowe” (2015), nr 7, s. 32-33.

\section{INNE MATERIAŁY}

Interpelacja nr $15866 \mathrm{w}$ sprawie wykładni przepisów ustawy o podatku od towarów i usług w zakresie sprzedaży gruntów rolnych, Sejm VIII kadencji, http://www.sejm.gov.pl/sejm8.nsf/interpelacja. xsp?documentId=E9AA9F950154D9D5C12581A900370FFF [dostęp: 2.10.2018].

Kolejna ofiara „Przyjaznego państwa”. Rolnik spod Jeleniej Góry nie wytrzymał konfrontacji z fiskusem i popełnił samobójstwo, https://wpolityce.pl/polityka/160589-kolejna-ofiara-przyjaznegopanstwa-rolnik-spod-jeleniej-gory-nie-wytrzymal-konfrontacji-z-fiskusem-i-popelnil-samobojstwo [dostęp: 27.09.2017].

Odpowiedź na interpelację nr 15866 w sprawie wykładni przepisów ustawy o podatku od towarów i usług w zakresie sprzedaży gruntów rolnych, Sejm VIII kadencji, http://www.sejm.gov.pl/sejm 8.nsf/interpelacja.xsp?documentId=E9AA9F950154D9D5C12581A900370FFF [dostęp: 2.10.2018]. 
Uzasadnienie do rządowego projektu ustawy o zmianie ustawy o podatku od towarów i usług oraz o zmianie niektórych innych ustaw, druk sejmowy nr 805, Sejm VII kadencji.

\section{KSZTAŁTOWANIE SIĘ LINII ORZECZNICZYCH W ZAKRESIE OPODATKOWANIA VAT SPRZEDAŻY PRZEZ ROLNIKÓW DZIAŁEK POD ZABUDOWE}

\section{Streszczenie}

Celem artykułu jest dokonanie przeglądu orzecznictwa dotyczącego jednej z najbardziej kontrowersyjnych kwestii, z jaką w ostatniej dekadzie przyszło się mierzyć właścicielom gospodarstw rolnych, tj. opodatkowania VAT sprzedaży nieruchomości pod zabudowę, które uprzednio były przeznaczone do użytkowania rolniczego. W pierwszej części opracowania przedstawiono linie orzecznicze, jakie ukształtowały się w polskiej judykaturze przed wydaniem przez Trybunał Sprawiedliwości Unii Europejskiej orzeczenia w sprawach połączonych C-180/10 i C-181/10. W drugiej części podjęto próbę ukazania wpływu rzeczonego orzeczenia na rozstrzygnięcia sądów krajowych. W trzeciej części przedstawiono zmiany w definicji legalnej działalności gospodarczej oraz wskazano linie orzecznicze, które ukształtowały się w okresie po wejściu w życie nowych regulacji. Opracowanie zostało przygotowane $\mathrm{w}$ ramach projektu badawczego finansowanego przez Narodowe Centrum Nauki: Nowy model opodatkowania rolnictwa w Polsce (nr wniosku 2013/09/B/HS5/04503, kierownik grantu dr hab. Paweł Smoleń, prof. KUL).

Słowa kluczowe: podatek od towarów i usług; gospodarstwo rolne; działalność gospodarcza; odpłatna dostawa nieruchomości

\section{THE DEVELOPMENT OF THE CASE LAW REGARDING VAT TAXATION OF THE SALE BY FARMERS OF THE LAND FOR TOWER BLOCKS}

\section{Summary}

The aim of this article is to review the jurisprudence regarding one of the most controversial issue with which the owners of agricultural holding had to dealt with in the last decade, namely the VAT taxation of the sale of the land for tower blocks which previously were intended for the agricultural use. The first part of this paper presents the case law that had developed in the Polish jurisprudence before the judgement of The Court of Justice of the European Union in joined cases C-180/10 and C-181/10. In the second part the attempt has been made to present the impact of the aforementioned judgement on national courts' rulings. The third part presents changes in the legal definition of economic activity as well as the case law which have developed after the entry into force the new regulation. The paper was prepared within the framework of the research grant awarded by the National Science Centre: A New Model of Taxing Agriculture in Poland (registration number 2013/09/B/HS5/04503, managed by PhD Paweł Smoleń, University Professor of KUL).

Keywords: tax on goods and services; agricultural holding; economic activity; supply of real estate for consideration 